\title{
The Role of Language in Anti-Immigrant Prejudice: What Can We Learn from Immigrants' Historical Experiences?
}

\author{
Kai Wei ${ }^{1}$, Daniel Jacobson López ${ }^{1}$ and Shiyou $\mathrm{Wu}^{2, * \mathbb{C}}$ \\ 1 School of Social Work, University of Pittsburgh, 4200 Fifth Ave, Pittsburgh, PA 15260, USA; \\ kaw153@pitt.edu (K.W.); DAJ57@pitt.edu (D.J.L.) \\ 2 School of Social Work, Arizona State University, 411 N. Central Avenue, Suite 800, Phoenix, \\ AZ 85004-0689, USA \\ * Correspondence: shiyou.wu@asu.edu
}

Received: 14 January 2019; Accepted: 20 February 2019; Published: 11 March 2019

\begin{abstract}
Prejudice remains an unpleasant experience in immigrants' everyday lives, especially for those of stigmatized groups. In the recurring struggle of various immigrant groups, historical and contemporary events reveal the important role of language in the creation, transmission, and perpetuation of anti-immigrant prejudice. Living in an anti-immigrant climate, immigrants are frequently exposed to stigmatizing language in both political and social discourse. This may be a more significant and frequent experience for immigrants since the beginning of the 2016 United States presidential election. Although it has long been understood that language is inextricably linked with prejudice, the investigation of the role of language in creating, transmitting, and perpetuating anti-immigrant prejudice remains undeveloped in social work research. This paper provides a theoretical explanation of anti-immigrant sentiment by discussing how stigmatization has allowed for immigrants to be subjected to various forms of prejudice throughout history. Building upon prior theoretical concepts of stigma, this paper argues that being an immigrant is a stigma. This paper reviews historical and contemporary cases of prejudice against immigrants to provide evidence for how stigmatizing language transmits and perpetuates anti-immigrant prejudice in the United States and building upon prior stigma theories, defines one's status of an immigrant to be form of stigma itself. The paper concludes with a call for appreciable attention to the role of language in anti-immigrant prejudice and the need for social workers to advocate for immigrants within higher education and in our communities to reduce such stigma though social work practice, education and research.
\end{abstract}

Keywords: anti-immigration prejudice; language; history; contemporary

\section{Introduction}

From private charity organizations to settlement houses, social workers have been at the frontier of work with immigrants (Padilla et al. 2008). As early pioneers, Jane Addams and Ellen Gates Starr founded the Hull house in Chicago, and their efforts in the settlement house movement were a landmark in social work practice. In her later practice, Jane Addams recognized the need for social workers to address social injustices experienced by immigrants in their everyday lives (Addams 1990; LaGumina 1999). As a practice-oriented profession, social work has always valued social justice as a core component of its profession (Webb 2006). The goal of social justice is to build a society without arbitrary or unnecessary suffering, exploitation, prejudice, and discrimination (Jost and Kay 2010). Similarly, The National Association of Social Workers' Code of Ethics similarly places value on core 
ethical principles of the profession, namely, social justice (NASW National Association of Social Workers). The NASW Code of Ethics states that social workers should strive to work on behalf of oppressed groups of people. Given the anti-immigrant climate today, advocating for social change therefore becomes an important and urgent task for social workers in the United States.

To date, 42.4 million immigrants are residing in this country (Pew Research Center 2017). Limited language skills and culture knowledge may play a role in inhibiting immigrants from integrating into a host society (Cervantes et al. 2013; Lara et al. 2005; Lopez-Class et al. 2011). However, their marginalized experience also derives from an environment in which they often experience prejudice, stigmatization, and ethnic profiling (Derose et al. 2007; Matthews 2003; Pérez 2010). As a foreign-born population, immigrants in the United States, are frequently exposed to stigmatizing language in political and social discourse in today's anti-immigrant climate. Immigrants exposed to such discourse in their daily lives were more likely to experience emotional distress (Sabo et al. 2014). As the largest immigrant group in the United States, Mexican immigrants (about a third of all immigrant populations) have been the primary targets of anti-immigrant prejudice for the past several decades (Chavez 2013). Although Mexican immigrants are currently the primary targets for anti-immigrant prejudice, they are not the only group that suffers from stigmatizing language and its related consequences.

Although it has long been understood that language is inextricably linked with prejudice, few studies have investigated the role of language in creating, transmitting, and perpetuating anti-immigrant prejudice. To address this research gap and yield a better understanding of recurring anti-immigrant dynamics, this paper reviews historical and contemporary cases of prejudice against immigrants to provide evidence for how stigmatizing language transmits and perpetuates anti-immigrant prejudice throughout United States history. This paper calls for appreciable attention to the role of language in anti-immigrant prejudice in social work practice and research. This is followed by an in-depth discussion about the role of language in prejudice with a focus on linguistic bias and the transmission of such bias through communication. Furthermore, this paper argues that one's immigrant status is a form of stigma, a further evolution of the conceptualization of stigma, most notably building about Howarth (2006) definition of race as stigma. We define immigrant status as stigma due to the complex nature of factors that result in anti-immigrant prejudice regardless of the specific immigrant group. This paper concludes with a call for appreciable attention to anti-immigrant prejudice and a need for advocacy within the social work field to reduce the stigmatization of immigrants both in social work practice and research.

\section{Theoretical Framework—Stigma Theory}

To best understand and conceptualize how various groups are separated and placed in a hierarchical order among one another, the conceptualization of stigma must be discussed. This discussion lends towards our understanding of how immigrant groups have been stigmatized and labeled by other groups in society. Goffman's original conceptualization of stigma (Goffman 1963) has been used by social psychologists as a way of understanding how people construct social categories and link these categories to stereotypes (Link and Phelan 2001).

Goffman (1963) set forth three criteria that constituted stigma: Blemishes of individual character, abominations of the body and tribal stigma (Major and O'Brien 2005, p. 395). Stigma is also considered a process; that individuals move through transitions of being labeled based on society's perception of them (Young et al. 2007). This is particularly relevant for immigrants who transition through different levels of stigmatization based upon their arrival and their perceived assimilation in the United States. Stigma additionally takes race and culture into account, as society determines which groups are to be stigmatized and which are not (Kusow 2004; Link and Phelan 2001), which often results from racialized language and policies. This allows us to better understand the application of stigma onto certain racial and/or ethnic immigrant populations. This paper proposes that one's immigrant status is also a stigma. 
Literature tends to view stigma as social construction, which can vary across time and culture (Kusow 2004; Major and O'Brien 2005). Since groups are labeled as deviating from a norm, or having a devalued characteristic, this stigmatization is dependent and based on the values and perceptions of a given society (Major and O'Brien 2005; Yang et al. 2007).

There are varying definitions of what constitutes stigma, as evidenced by the terminology by various researchers and this paper builds upon former conceptualizations of theory. Goffman (1963) defines stigma as a discrediting characteristic (Albrecht et al. 1982; Link and Phelan 2001; Major and O'Brien 2005). Stafford and Scott (1986) define stigma as a characteristic that is contrary to a norm (Link and Phelan 2001). Other definitions include those by Crocker et al. (1998), who define stigma as a social identity that is devalued by society (Major and $\mathrm{O}^{\prime}$ Brien 2005), such as is the case with the identity and status of being an immigrant. Most theorists agree that stigma is socially constructed (Yang et al. 2007).

While stigma is a social construct, it does have long lasting effects on those who are stigmatized (Link and Phelan 2001; Major and O'Brien 2005). Stigma can result in discrimination, labeling, and negative stereotyping (Kusow 2004; Link and Phelan 2001; Yang et al. 2007). We have seen such acts of discrimination based on immigrant status reflected in recent immigrant policies in the United States, such as with the Muslim ban and the separation of Latinx families (Minoff 2018; Sidiqqui 2018).

Researchers also proposed that stigmatization occurs when a person receives a mark- a deviation from the norm has been linked to them (Kurzban and Leary 2001; Yang et al. 2007). This mark is what separates the individual from the rest of society and affects the way society reacts to them based on the stigma assigned to them (Kurzban and Leary 2001). The second variation defining stigma was proposed by Elliott and colleagues (Elliott et al. 1982), which proposes that stigma is a form of deviance which causes others to judge them and excludes them from participation in society (Kurzban and Leary 2001). The third variation was proposed by Crocker et al. (1998), stating that there is often not one single characteristic that determines an individual's stigmatization but rather their belonging to a particular group that is stigmatized (Kurzban and Leary 2001). This definition of stigma applies to immigrants who by belonging to a given group (e.g., Chinese, Mexican, Muslim) are stigmatized and individually discriminated against based on their belonging to the larger stigmatized group. While this definition includes immigrants, we further expand upon this definition and propose that being an immigrant is a stigma.

The closest definition of stigma to which we build from is that of Howarth (2006). Howarth (2006) defines race as a possible stigma. Howarth (2006) addresses the social construction of race, acknowledging that one's race cannot be seen or physically observed by others, but can be inferred by physical characteristics such as skin tone. For example, Howarth (2006) definition of stigma is fitting when addressing how Chinese immigrants were referred to as the yellow peril and the current fear of The Browning of America, both referencing skin tones of certain racial/ethnic groups. Howarth (2006) definition of stigma includes race and skin tone, which can include immigrants who have a darker skin tone or are from different areas of the world, which makes them subject to being stigmatized due to their race and/or ethnicity.

We expound upon Goffman (1963), Crocker et al. (1998), and Howarth (2006) definition of stigma, which categories stigma as a mark or even race. Immigrants can be separated based on their belonging to their social category as immigrants, as well as being grouped by their nationality, ethnicity or religious-affiliation. As immigrants can be categorized and stigmatized based on nationality, race/ethnicity, and religion, they are therefore labeled and stigmatized simply for being an immigrant. The prior definitions set forth by Crocker et al. (1998), Goffman (1963) and Howarth (2006), all lend credibility towards how immigrant status is a form of stigma, as they incorporate the aspects towards being labeled, being stigmatized due to one's belonging to a particular group and one's race. Immigrants are incorporated into each of these categories. For example, the recent anti-Mexican language and erroneous descriptions of Mexicans in the United States, constitute a form of stigma towards Mexican immigrants based on their nationality (Mexican) and their ethnicity 
(Latinx). Therefore, we argue that one's immigrant status (Mexican immigrant) is a stigma itself, which incorporates their belonging to a larger group, as well as their race and/or ethnicity. The recent Muslim ban, upheld in 2018 by the United States Supreme Court (Sidiqqui 2018), is a discriminatory policy based on an immigrant's religion (Islam) and has resulted in discriminatory policies based on that individual's belonging to a group, consistent with Crocker et al. (1998). As such, we propose that immigrant status is a stigma within itself, as their status as immigrants results in being labeled, marked as different from the norm, incorporates their belonging to a larger group, often is due to their race and/or ethnicity, and can result in discrimination. It is therefore evident that immigrant status is a stigma.

\subsection{Recurring Dynamics of Anti-Immigrant Prejudice}

Anti-immigrant prejudice has recurred for every major immigration wave since the early $1800 \mathrm{~s}$ (see Table 1 for details). Immigrants who once suffered from anti-immigrant prejudice transferred the prejudice to which they were subjected onto the newly arrived immigrants (Barrett 1992). Each recurrence of anti-immigrant sentiment follows a distinct pattern: a newly arriving immigrant group is perceived as a threat to established group interests, the threatened groups brand immigrants with stigmatizing labels and rhetoric and this stigmatization gives rise to, reinforces, and perpetuates anti-immigrant prejudice. As this pattern is predictable and consistent, it allow for social workers to be able to actively work towards developing interventions to reduce anti-immigrant language through programming and interventions in order to reduce the stigma placed onto immigrants.

Large numbers of incoming immigrants are perceived as disrupting established order and threatening established interests, and as such, justify social responses to mitigate the harmful effects of these disruptions on settled Americans and immigrants. However, stigmatizing language and anti-immigrant prejudice lead to sanctioned social responses (grassroots driven and top-down policy driven) that are often harmful to immigrants or discriminate in ways that diminish social justice for all Americans. Extreme stigmatizing rhetoric also leads to extreme forms of violence, such as hate crimes (including lynching, Allport 1954). Unfortunately, these forms of violence against immigrants have historically been socially sanctioned.

Although the pattern of viewing immigrants as a perceived threat, and then being labeled and stigmatized and consequently being subjected to various forms of prejudice is recurring, the specific manifestations of each recurrence differs in ways that reveal the complex social, economic, and cultural forces that drive anti-immigrant prejudice in the United States. This pattern of anti-immigrant sentiment for several distinct immigrant populations is first reviewed (e.g., Irish, German, Chinese, Mexican, and Muslim). This historical review of anti-immigrant prejudice highlights the various social responses towards immigrants in the United States and allows us to understand the contemporary treatment of immigrants as well as to tailor interventions to reduce the stigmatization of immigrants. 
Table 1. Manifestations of anti-immigrant prejudice across different groups in the United States.

\begin{tabular}{|c|c|c|c|c|c|c|c|c|}
\hline \multirow[b]{2}{*}{$\begin{array}{l}\text { Manifestations of } \\
\text { Anti-Immigrant } \\
\text { Prejudice }\end{array}$} & \multirow[b]{2}{*}{ Descriptions } & \multicolumn{7}{|c|}{ Examples of across Different Immigrant Groups in the United States } \\
\hline & & $\begin{array}{l}\text { Irish Immigrant } \\
\text { (1830s-1850s) }\end{array}$ & $\begin{array}{c}\text { German } \\
\text { Immigrant } \\
(1850 \text { s-WWI) }\end{array}$ & $\begin{array}{l}\text { Italian Immigrant } \\
\text { (1880s-WWI) }\end{array}$ & $\begin{array}{l}\text { Chinese Immigrant } \\
\text { (1850s-1870s) }\end{array}$ & $\begin{array}{c}\text { Japanese } \\
\text { Immigrant (WWII) }\end{array}$ & $\begin{array}{l}\text { Mexican Immigrant } \\
\quad \text { (Post-1965) }\end{array}$ & $\begin{array}{l}\text { Muslim Immigrant } \\
\text { (Post-9/11) }\end{array}$ \\
\hline $\begin{array}{l}\text { Prejudicial } \\
\text { language }\end{array}$ & $\begin{array}{l}\text { Negative } \\
\text { connotative } \\
\text { language } \\
\text { describing } \\
\text { immigrants such } \\
\text { as hate speech }\end{array}$ & $\begin{array}{l}\text { They were called } \\
\text { white negroes } \\
\text { (Houstoun 1850), } \\
\text { alcoholics, and } \\
\text { Pagans (Berger 1946). }\end{array}$ & $\begin{array}{c}\text { They called } \\
\text { anarchist, extremist, } \\
\text { hyphenated-American, } \\
\text { incendiary, } \\
\text { extremists, radical, } \\
\text { and traitor (Allport } \\
\text { et al. 1954; Kennedy } \\
\text { 2004). }\end{array}$ & $\begin{array}{l}\text { Italian immigrants } \\
\text { were called dago, } \\
\text { alien hordes, } \\
\text { criminals, mafia, } \\
\text { Italian loafer, and } \\
\text { slippery (Higham } \\
\text { 2002; LaGumina } \\
\text { 1999) }\end{array}$ & $\begin{array}{l}\text { They were called as } \\
\text { yellow peril, } \\
\text { barbarians, and } \\
\text { enraged coolie } \\
\text { (Young 2014) }\end{array}$ & $\begin{array}{c}\text { They were called } \\
\text { the yellow bastards, } \\
\text { a Jap, a yellow-belly } \\
\text { Jap, and a } \\
\text { Jap-a-Nazi-Rat } \\
\text { (MacDougall 1999) }\end{array}$ & $\begin{array}{l}\text { They were called } \\
\text { "criminals" and } \\
\text { "rapists" (Kohn 2015). }\end{array}$ & $\begin{array}{l}\text { They were called } \\
\text { radical, jihad, and } \\
\text { terrorists (Ali 2012; } \\
\text { Kundnani 2014). }\end{array}$ \\
\hline Discrimination & $\begin{array}{c}\text { Intention of } \\
\text { disadvantaging } \\
\text { immigrants such } \\
\text { as employment } \\
\text { exclusion }\end{array}$ & $\begin{array}{l}\text { Irish immigrants were } \\
\text { disproportionally } \\
\text { represented in the } \\
\text { number of arrests, } \\
\text { imprisonment, and } \\
\text { confinement in } \\
\text { poorhouse and } \\
\text { mental hospitals } \\
\text { (Casey and Lee 2007). }\end{array}$ & $\begin{array}{c}\text { German language } \\
\text { was not forbidden } \\
\text { to use in any public } \\
\text { place in Iowa } \\
\text { (Kennedy 2004). }\end{array}$ & $\begin{array}{l}\text { Italian immigrants } \\
\text { were } \\
\text { disproportionally } \\
\text { represented in } \\
\text { criminal justice } \\
\text { system with charges } \\
\text { such as blackmail } \\
\text { and assaults in New } \\
\text { york City during } \\
\text { early 1920s } \\
\text { (LaGumina 1999). }\end{array}$ & $\begin{array}{l}\text { In } 1854 \text {, People v. } \\
\text { Hall ruled that } \\
\text { Chinese could not } \\
\text { testify against white } \\
\text { people due to the fact } \\
\text { that Chinese were an } \\
\text { inferior race with } \\
\text { insufficient } \\
\text { intelligence to testify } \\
\text { (People v. Hall 1854). }\end{array}$ & $\begin{array}{l}\text { More than } 100,000 \\
\text { Japanese } \\
\text { immigrants and } \\
\text { Japanese Americans } \\
\text { were incarcerated in } \\
\text { concentration } \\
\text { camps whose only } \\
\text { crimes were having } \\
\text { an un-American } \\
\text { identity-Japanese } \\
\text { (Robinson 2009) }\end{array}$ & $\begin{array}{l}\text { In early 1900s, } \\
\text { Mexican repatriation } \\
\text { removed more than } \\
400,000 \text { Mexican } \\
\text { American citizens } \\
\text { (California Senate Bill } \\
\text { No. 670, 2005). }\end{array}$ & $\begin{array}{c}\text { Following the } 9 / 11 \text {, } \\
\text { there was an } \\
\text { exponential increase } \\
\text { of hate crimes and } \\
\text { bias incidents (e.g., } \\
\text { airline profiling) } \\
\text { targeting at Arabs } \\
\text { and Muslims } \\
\text { Americans (Alsultany } \\
\text { 2012, 2013). }\end{array}$ \\
\hline Physical attack & $\begin{array}{l}\text { Acts of violence } \\
\text { against } \\
\text { immigrants }\end{array}$ & $\begin{array}{l}\text { Rioters in Boston } \\
\text { burned Irish } \\
\text { immigrants' houses } \\
\text { and forced them to } \\
\text { leave their homes } \\
\text { (Calavita 1984). }\end{array}$ & $\begin{array}{l}\text { German immigrants } \\
\text { were physically } \\
\text { attacked. For } \\
\text { example, a man in } \\
\text { Wyoming were } \\
\text { hanged and made } \\
\text { to kneel and kiss } \\
\text { the American flag } \\
\text { (Kennedy 2004). }\end{array}$ & $\begin{array}{l}\text { In August 1920, } \\
\text { local mobs } \\
\text { firebombed the } \\
\text { Italian quarters, } \\
\text { killing one Italian } \\
\text { immigrant, injuring } \\
30 \text {, and destroying } \\
\$ 20,000 \text { in property } \\
\text { (Mormino 2002). }\end{array}$ & $\begin{array}{l}\text { Chinese's homes and } \\
\text { businesses were } \\
\text { burned (Takaki 1990). }\end{array}$ & $\begin{array}{c}\text { Japanese } \\
\text { immigrants were } \\
\text { physically attacked } \\
\text { after the release of } \\
\text { The Cheat, an } \\
\text { anti-Japanese film } \\
\text { (Miyao 2007). }\end{array}$ & $\begin{array}{l}\text { Mexican immigrants } \\
\text { and Mexican } \\
\text { Americans were } \\
\text { physically attacked } \\
\text { because they were } \\
\text { also perceived as } \\
\text { economic threat, and } \\
\text { because they spoke } \\
\text { Spanish too loudly } \\
\text { and acted too } \\
\text { Mexican (Carrigan } \\
\text { and Webb 2003). }\end{array}$ & $\begin{array}{l}\text { From } 2000 \text { to } 2001 \text {, for } \\
\text { example, hate crimes } \\
\text { against Arabs and } \\
\text { Muslims increased } \\
\text { from } 117 \text { to } 1915 \\
\text { (FBI 2001). }\end{array}$ \\
\hline Extermination & $\begin{array}{l}\text { Removal of } \\
\text { immigrants by } \\
\text { any means such } \\
\text { as lynching }\end{array}$ & & $\begin{array}{c}\text { A German } \\
\text { immigrant was } \\
\text { lynched near St. } \\
\text { Louis in April 1918 } \\
\text { (Kennedy 2004). }\end{array}$ & $\begin{array}{l}\text { In 1891, } 11 \text { Italian } \\
\text { immigrants were } \\
\text { lynched in New } \\
\text { Orleans, Louisiana } \\
\text { (Gambino 1977). }\end{array}$ & $\begin{array}{l}\text { In Los Angeles, } 18 \\
\text { Chinese immigrants } \\
\text { were systematically } \\
\text { killed, one of the } \\
\text { largest incidents of } \\
\text { mass lynching in } \\
\text { United States history } \\
\text { (Dorland 1894). }\end{array}$ & $\begin{array}{c}\text { Outside the Tally } \\
\text { Theater, a Japanese } \\
\text { noodle shop owner } \\
\text { was lynched (Miyao } \\
\text { 2007). }\end{array}$ & $\begin{array}{l}\text { Between } 1848 \text { and } \\
1928, \text { mobs lynched at } \\
\text { least } 597 \text { Mexicans in } \\
\text { the United States } \\
\text { (Carrigan and Webb } \\
\text { 2003). }\end{array}$ & \\
\hline
\end{tabular}


In the 1840s, a large number of Irish immigrants began arriving in the United States to escape potato famine and other deprivations arising from political conflicts between Ireland and Britain. By 1850, the Irish accounted for $44 \%$ of the total immigrant population in the United States (Kennedy and Kennedy 1964), and settled primarily in large cities in the northeastern United States, such as Boston, New York, and Philadelphia. The political and economic elite welcomed the newly arriving immigrants because they provided a superabundance of cheap labor to fuel the U.S. growth. As President Tyler explained to Congress on June 1841, "We hold out to the people of other countries an invitation to come and settle among us as members of our rapidly growing family" (Richardson 1908 , p. 41). However, many working class Americans viewed Irish immigrants as posing an economic threat: their pauperism as Americans workers (Mitchell 1862). In large numbers, Irish immigrants replaced U.S. adult male labor in factories, and replaced American women and child workers in textile mills (Handlin 1941). American workers attributed the blame to Irish immigrants for their loss of jobs, rather than to the owners of factories and textile mills, or to external economic causes. The middle-class took a characteristically different view: they perceived Irish immigrants as posing a threat to the stability of social and economic order as a consequence of rising pauperism (Crenson 1998) and as Catholic immigrants differentiating themselves from the dominant middle-class Protestant population. Consistent with Jones and colleagues' (1984) definition of stigma, which states that stigma occurs when an individual receives a mark that deviates them from the norm. As is the case with Irish immigrants, their Catholicism was viewed as a deviation from Protestantism, which consequently led to them as receiving a mark, separating them apart from the dominant society.

Irish immigrants were labeled as the worse plague of all (Martineau 1837), white negroes (Houstoun 1850), alcoholics, and Pagans (Berger 1946). These prejudicial labels induced and reinforced American workers' anxious and angry feelings, and provoked violent nativist and anti-Catholic riots, including burning immigrants' homes and churches (Arnold 2011). Armed conflict between American workers and Irish immigrant workers occurred repeatedly on the railroads and in the textile mills in 1844 (Feldberg 1975), and by the 1850s, armed conflicts were occurring in nearly every state (Calavita 1984). Political movements also arose that were explicitly opposed to immigration (e.g., the Know Nothing Party from 1854 to 1856). The intergroup conflicts between Irish immigrants and Americans were primarily caused by different economic interest and religious differences. The stigmatizing labels encoded American workers' antipathy and loathing about immigrants reflect nothing more than their blaming of Irish immigrants for their own economic insecurity and concerns about potential threats from a different religion. This stigmatization of Irish immigrants is also consistent with Crocker et al. (1998), who set forth that one's belonging to a certain group constitutes stigma as well as the findings that stigma often results in discrimination, labeling, negative stereotyping and violence (Allport 1954; Kusow 2004; Link and Phelan 2001; Yang et al. 2007).

\subsubsection{Anti-German Prejudice}

Prior to World War I, German immigrants were regarded as the most esteemed immigrant group, in part because they settled in rural rather than urban areas, and therefore did not compete with low-skilled labor workers. German immigrants also fit the dominant White Anglo-Saxon Protestant culture (Kennedy 2004). All of this changed, however, with the advent of World War I, when they were perceived as direct threats to American security, and in the disruptive aftermaths of the war such as the Red Scare ${ }^{1}$, when German immigrants and settled Germans alike were perceived as threats to American culture and social order.

In the public eye, German immigrants became the group who had no intention of becoming Americans (Park 1914). The term German became stigmatizing in and of itself, essentially becoming equated with being un-American and disloyal (Gordon 1964). German immigrants and settled Germans

1 The Red Scare refers to the fear of socialist revolution, communism, and political radicalism since World War I. 
were labeled as extremists, hyphenated-Americans, incendiaries, radicals, and traitors (Kennedy 2004). German words, such as hamburger and sauerkraut, were replaced by terms such as liberty sandwich and liberty cabbage. In Iowa, the governor forbade speaking German language in public (Kennedy 2004). Near St. Louis, Missouri, a German immigrant was stripped and bounded with American flag, and eventually "lynched to the lusty cheer of five hundred patriots" (Kennedy 2004, p. 68). The lynch mob was charged but found not guilty, a result described in the Washington Post as "a healthful and wholesome awakening in the interior of the country" (Peterson and Fite 1986, pp. 202-7). Despite the fact that German immigrants fit into White Anglo-Saxon Protestant culture, their status changed after World War I. Different from the anti-Irish immigrant experience, anti-German prejudice showcases the dynamic process of anti-immigrant prejudice where hostility against immigrants can rise from conflicting interests residing from international relationships. In addition, the words that depict German immigrants after the war reflect Americans' heightened perceived threat of outsiders and served as a justification for enacting violence against German immigrants. The experience of German immigrants is notable in that their status and acceptance in the United States deteriorated over time as a result of political and social occurrences in history. German immigrants' experience of stigma is consistent with literature that acknowledges that stigma is based on the values of perceptions of a society, varying across time (Major and O'Brien 2005; Yang et al. 2007).

\subsubsection{Anti-Chinese Prejudice}

During the 1850s, a significant number of Chinese immigrants seeking economic opportunity and escape from war and political upheaval began to arrive on the U.S. west coast. As was the case with Irish immigrants, Chinese immigrants were a cheap source of labor for U.S. businesses eager to maximize profits. In fact, the credit-ticket emigration system legalized the contractual relationship between Chinese laborers and brokerage companies, and constituted a barely-disguised form of slave trade (Barth 1964). American workers as well as other immigrants (Irish immigrants, in particular) accordingly perceived Chinese immigrants as economic threats to unskilled labor jobs (Goloboy 2009). They accused Chinese immigrants of reducing the U.S. labor standards to "the Chinese standard of rice and rats" (Takaki 1990, p. 234). Chinese immigrants were also perceived as being racially inferior, and as a threat to American racial identity. Racism was, at that time, sustained by scientific racism as well as race-based laws (Dred Scott v. Sandford 1857) that served as a legal basis for slavery in the United States.

Chinese immigrants were labeled as Asiatic blood, yellow peril, barbarians, and enraged coolie (Young 2014), and portrayed in a publisher, the Hearst-dominated print media, as purveyors of opium and seducers of white women (Provine 2007). Chinese immigrants were stigmatized and violently persecuted as a result of this stigmatization, consistent with Allport (1954), Kusow (2004), and Yang and colleagues (Yang et al. 2007). An incident in Los Angeles involved the lynching of 18 Chinese immigrants remains the worst mass lynching in U.S. history (Dorland 1894). However, the lynch mob was never punished because a California Supreme Court judge ruled that Chinese witnesses could not testify against white people on the legal basis that Chinese were an inferior race with insufficient intelligence (People v. Hall 1854). In the late 1870s, "Chinese Must Go" became the slogan for the Workingmen's Party of California (Gyory 1998, p. 111). Perhaps most notably, the Chinese became the first illegal aliens in the United States with the passage of the Chinese Exclusion Act of 1882 and its amendment in 1891, which included penalties of imprisonment and deportation (Young 2014). The experience of Chinese immigrants revealed a more complicated mechanism that intersects anti-immigrant prejudice with Americans' racial bias. Compared to earlier wave immigrants (Irish and German), Chinese immigrants were the first to be legally excluded for the reason that their inferior race posed threat to American identity. These racial biases are transmitted through words such as yellow peril, which use the biological traits of Chinese to justify the legality of social exclusion. While we agree that these various forms of violence, and legalized discrimination are forms of stigmatization we due to their race (Howarth 2006), we contend that the status of being an immigrant is a stigma 
itself. While the complex mechanism by which Chinese immigrants were subjected to anti-immigrant sentiment showcases the various forms of discrimination, we argue that their status of being immigrant alone stands as a stigma.

\subsubsection{Anti-Mexican Prejudice}

Since the earliest days of the United States, Mexicans lived, worked, and were woven into the social fabric of the U.S. southwest. Mexico and Canada were unique in not being subjected to immigration quotas. This changed with the advent of the 1965 Immigration Reform Act, which imposed quotas on Mexican immigration. However, long-established immigration patterns and customs were regarded as violations of U.S. law. The extent to which the status quo was disrupted is apparent in raw numbers: circa 2015 there were 5.6 million undocumented Mexican immigrants, from a total of 9 million undocumented Latino immigrants (Gonzalez-Barrera and Krogstad 2015; Passel and Cohn 2014).

One effect of this disrupted status quo is the emergence of Latino Threat Narrative (Chavez 2013). Chavez (2013) observed that from 1965 to 2000, two-thirds of the national magazine coverage on immigration described Latinos, particularly Mexican immigrants, as being unwilling or incapable of integrating into U.S. society and as being invaders who may destroy the U.S. status quo. This threat narrative continued to appear widely in media, political discourse, and everyday conversations (Fujioka 2011; Massey and Pren 2012; Santa Ana 2002). Mexicans are dehumanized and stigmatized as an out-group in through linguistic mechanisms in phrases such as, they are taking our jobs, they are diseased, and they are criminals (Streitmatter 1999). As an out-group, Mexican immigrants are perceived as threats to American cultural identity who would Hispanicize Americans (Monotgomery 2013), and as dividing the nation into "two peoples, two cultures, and two languages" (Huntington 2004 , p. 30). This similar separation of groups is consistent with the notion that stigma pertains to a social group which is devalued by society (Crocker et al. 1998) and one that is socially constructed (Yang et al. 2007). In the heated 2016 U.S. presidential campaign discourse, the stigma of being labeled as violators of immigration law translated to Mexican immigrants being labeled as vile criminals and being referred as rapists and murders (Kohn 2015). This racist, anti-immigrant and anti-Mexican sentiment has also resulted in the separation of Latinx families in the United States (Minoff 2018), which has garnered considerable national attention. Similar to Chinese immigrants, Mexican immigrants not only are perceived as posing an economic threat, but also as a threat to the American identity, due to their race/ethnicity and culture, which echoes Howarth (2006) definition of stigma. Adding onto these theorists, it is evident that their status of an immigrant is a stigma, as evident by how the use of anti-immigrant language, racist rhetoric and defamatory references. However, the language used towards Mexicans that revealed racial prejudice against Mexicans has become subtler due to the change of Americans' racial bias following civil rights movements, exemplifying that race is a stigma as set forth by Howarth (2006). This subtle language use that exemplifies Americans' intentions to exclude Mexicans by the use of the words "we" (ingroup) and "they" (outgroup), where Mexicans have been ascribed as an out-group. The language description of Mexican immigrants as an outgroup in public discourse has been consistent with restrictive immigration policies that deport a disproportionate number of Mexican immigrants from the United States compared with other immigrant groups.

\subsubsection{Anti-Muslim Prejudice}

The experience of established Muslims and Muslim immigrants is similar in one respect to the experience of Germans: intense prejudice arising from conflicts with foreign entities, which constitutes forms of stigma (Young et al. 2007). The shock of the 9/11 terror attacks and the ensuing conflicts with nebulous non-state terrorist actors (Cole 2009) has led to widespread perception that terrorism imposes a threat on U.S. soil. The rise of Islamic Terrorism, in which terrorists act in the name of Islam and have no single national origin (Sheridan 2006), has induced prejudice against Arab and Muslim immigrants in general, and in particular to those who also practice Islam. A growing number of scholars have 
labeled the post-9/11 response to the threat of terror directed towards Arab and Muslim Americans and immigrants as Islamophobia, i.e., a sense of fear or hatred towards anyone of Islamic belief (Sheehi 2011). The anti-immigrant sentiment and stigma of Muslim immigrants is a result of their belonging to the Islamic faith and is associated with a devalued characteristic (their religion), exemplifying forms of stigma (Crocker et al. 1998; Major and O’Brien 2005).

Muslims as a whole are labeled as radical, extremist, and as potential terrorists (Kundnani 2014). Following 9/11, there has been a sharp increase of hate crimes and bias incidents (e.g., airline profiling) targeting Arab and Muslim Americans (Alsultany 2013). Between 2000 and 2001, hate crimes against Arabs and Muslims increased tenfold, from 117 to 1915 (FBI 2001). Anti-Muslim prejudice has become more prevalent following the Paris attack on 13 November 2015, the San Bernardino attack on 2 December 2015 and the Orlando attack on 2 June 2016, with reported hate crimes towards Muslims tripling after the 2015 attacks, including physical assaults on hijab-wearing students, arsons and vandalism at mosques, and shooting and death threats at Islamic-owned businesses (Lichtablau 2015). Victims of hate crimes were found to be more likely to suffer from emotional stress, such as depression and anxiety (Awan and Zempi 2015). Anti-Muslim immigrant prejudice is complicated with external threat, which is a similar case as with German immigrants, and well as being tied with their religion. The words that describe these two groups can provide some insights. While German immigrants were referred to as traitors during World War I, while Muslim immigrants are referred to as terrorists. These assigned labels suggest a splitting in how Americans perceive these two groups in terms of their belonging to the United States, consistent with the definition of stigma by Crocker et al. (1998). A traitor (although a negative label) belongs to a given country, whereas terrorist does not. The differences in language use reflect and constrain how we conceptualize different immigrant groups.

\subsection{The Deep Commonality of Anti-Immigrant Dynamics}

This review of anti-immigrant prejudice across multiple groups (Irish, German, Chinese, Mexican, and Muslim) provides insight for the dynamics of prejudice within a group (surface level) and across multiple groups (deep level). At the surface level, each group has its unique sufferings from prejudice. For example, the prejudice experienced by German immigrants is different from that experienced by Chinese immigrants. However, with some careful investigation we can identify deeper commonality among their experiences, as each recurrence of stigmatization follows a pattern:

1. Established groups perceive a newly arriving immigrant group as a threat.

2. The threatened groups encode perceived threat in biased language that brands immigrants with stigmatizing labels in social discourse and rhetoric.

3. When biased language becomes systematic, it perpetuates anti-immigrant prejudice, gives rise to discriminatory laws (e.g., exclusion acts), and in the minds of some, sanctions criminal behaviors (e.g., hate crimes and lynching).

As previously mentioned, each immigrant group has experienced various forms of anti-immigrant prejudice, and are stigmatized for their race/ethnicity, religion, nationality, belonging to their specific group as well as being vulnerable to social and political historical contexts. As we have outlined the various forms of stigmatization which each unique immigrant group has endured, as according to the theorists, they are some similarities among all groups. Each group has been subject to the social and political climate, which often has determined their experiences of anti-immigrant sentiment. Stigma theorist have readily recognized this occurrence (Kusow 2004; Major and O'Brien 2005; Yang et al. 2007). Chinese, Mexican and Muslim immigrants' stigmatization is due to their ethnicity, culture, and race, the latter of which Howarth (2006) considers to be a stigma. As we recognize and acknowledge the commonalities and differences of anti-immigrant prejudice among the varying immigrant groups, we claim that one's identity of an immigrant is a stigma. Similar to Howarth (2006), definition of race as a stigma, we likewise define one's status as an immigrant to be a stigma. While each immigrant group was attacked due to their status of being an immigrant, whether it was due to 
their race/ethnicity, nationality, or religion; all groups were targeted because they were immigrants. While we certainly acknowledge the unique differences in their subjugation and readily take race, skin color, and religion into account of our proposal, we clearly consider one's status of an immigrant to be a stigma.

\section{The Role of Language in Anti-Immigrant Prejudice}

Biased language plays a central role in influencing anti-immigrant prejudice at micro and macro level processes. A full understanding of this central role of language provides insights for social work interventions.

A tenant of cognitive linguistics is that language and cognition are intimately related, and in particular language constrains what we think, what we communicate, and how we interpret communication (Lakoff and Johnson 2008). Nouns and adjectives (abstract language) serve to perpetuate negative evaluation of different groups (Porter et al. 2015). The levels of language abstraction can indicate our attitudes, expectation, and beliefs about others, which in turn, can be passed on to those with whom we communicate (Fiedler 2011). Generally, individuals holding negative attitudes towards group members are more like to use abstract language to describe negative behaviors of these groups and use concrete language to describe their positive behavior, and vice versa (Maass 1999).

\subsection{Linguistic Bias and Prejudice}

Systematic bias in language use can, in subtle ways, serve to transmit and perpetuate negative evaluations and prejudice against different groups (Maass 1999). Immigrant groups, regardless of their country of origin, were perceived as a threat at the time of their arrival in the United States. To perpetuate prejudice towards these groups, the established groups fix their negative evaluation in words by using abstract language to dehumanize immigrant groups. In the description of immigrants, emotion-toned labels have been used in historical and contemporary context with an intention not only to characterize immigrants' membership, but also to disparage and reject them (Allport 1954). For example, the labels Asiatic blood and yellow peril not only characterize Chinese immigrants as racially different, but they also imply deviation from a desirable race and, therefore, Chinese are seen as a threat to the (desirable) Whiteness of the nation (Young 2014). The anti-immigrant sentiment and stigma is racial, as set forth by Howarth (2006). Similar examples can be seen in recent discussions of the Browning of America (Monotgomery 2013). The word illegal not only serves a legal distinction of immigration status, but also dehumanizes immigrants and conveys a message of rejection and exclusion (López 2012). These emotion-toned labels serve to vilify immigrants as being deviant and to transmit and perpetuate the prejudice and stigma of immigrant groups and are transacted through people's day-to-day communication.

\subsection{Communication Process and the Transmission of Prejudice}

Hall (1980) formulated an encoding/decoding model of communication in which communicants function in one of two roles: as message senders (organize one's feelings and thoughts into language conveyed to others), and message receivers (understand and interpret the language conveyed from others). Hall (1980) model has important implications for understanding the relation of language and prejudice in communication processes. The words chosen by a sender will reflect the feelings and thoughts of the sender about certain issues and groups. For example, when describing a gay individual, a biased sender will more likely to use the word fag, while less biased senders might use gay (Carnaghi and Maass 2007). The way receivers interpret messages from a sender will analogously be shaped by and possibly amplify the receiver's prior feelings and thoughts about those issues and groups. For example, Pearson (2010) found that using the term illegal aliens generates more prejudice towards Mexican immigrants than using the term undocumented workers. 
In some cases, communication is one way. Where the communication is one way, the receiver is not simply passively interpreting messages but rather experiencing a sequence of cognitive responses and emotional feelings (Scheufele and Tewksbury 2007). In the process of news exposure, for instance, media outlets (sender) can shape their consumers' opinions (receivers) (Bakshy et al. 2015). Research has showed that individuals' prejudice towards immigrants can be amplified if they rely on media as their primary source of information where that source frequently reports negatively about immigration issues, such as associating immigrants with increasing crime rates or reducing job opportunities (White et al. 2012).

Collins and Clément (2012) also proposed the important role of social norms that can moderate the relationship of language and prejudice. This role can be understood in a cross-national context as well as within a nation. The expression of prejudiced beliefs using offensive language is more socially tolerated in the United States than that in the United Kingdom. In the United Kingdom, a series of hate speech laws were passed to regulate language use in public. For example, The Racial and Religious Hatred Act of 2006, forbade the use of threatening words in any written materials that expresses religious hate. Within the United States, the expression of biased opinions about immigrant groups, such as their race and ethnicity, may be more socially acceptable in online social network platforms than in day-to-day interactions with members of different groups.

Language can also differentially influence the feelings and thoughts of receivers according to their group membership. These differential effects can be illustrated in the following three conditions. First, for individuals who perceive immigrants as threats, the exposure of biased language use about immigrants may reinforce their prejudicial attitudes (Igartua et al. 2012). Second, for individuals who do not perceive immigrants as threats, the exposure of biased language may induce their prejudicial attitudes. Third, based on social identity theory (Stets and Burke 2000), for immigrants who are perceived as threats, the exposure of biased language about themselves may lead to these immigrants to internalize bias (accept the bias), externalize bias (express hate toward society), or both. In addition to internalized and externalized bias, some immigrants may also choose to finger-point at their own group members (whom they think represent certain labels) or choose to collectively respond to bias. Language can encode individuals' prejudices, which in turn, can pass down through day-to-day interactions with members of different groups. The language encoded prejudice not only has a negative effect on perceiver attitudes about a group, but also influence the self-perception of targeted groups.

\section{Conclusions and Implications}

This paper examines the dynamics of anti-immigrant prejudice in the United States and proposes that immigrant status constitutes stigma. History and contemporary events reveal the recurring struggle of vulnerable and socially marginalized immigrants: they are perceived as economic, cultural and security threats, assigned stigmatizing labels and narratives, and face prejudice and discrimination. While each group encountered unique challenges and experiences of anti-immigrant sentiment specific to their race/ethnicity, nationality, skin-tone and religion, each group experienced prejudice and discrimination because of their immigrant status. Therefore, it is evident one's immigrant status is a stigma.

With each recurrence, structural barriers are erected that limit the economic, political and social rights and opportunities of immigrants. Social work research and practice needs to actively resist anti-immigrant prejudice and discrimination if it is to fulfill its mission in promoting social justice, where all individuals are treated with dignity and respect. Although immigrant welfare has long been a concern to social work, the contemporary immigrant experience demonstrates the extreme need for social work to imminently and actively work to achieve its mission of social justice. It is incumbent upon all social workers to advocate for immigrants who are subject to prejudice, discrimination, and violent acts, both in practice and policy. While reviewing the literature of language on anti-immigrant bias, it is apparent that social workers must actively work to educate and intervene to combat such language. Social workers can actively work to educate others about the effects that such 
biased language has on immigrants and society as well as propose appropriate and non-stigmatizing language to be used in classrooms, daily conversations and the work place.

\subsection{Implications for Social Work Research}

In recent years, there has been a growing consensus among social work educators to promote social justice, address social stigma, and reduce structural barriers. Despite being at the forefront of working with immigrants, this consensus has not led to appreciable attention in social work practice to marginalized immigrant populations who have been stigmatized and are confronted by punitive immigration laws that reflect and reinforce contemporary forms of anti-immigrant stigma. Although we should avoid the irony of assigning negative stereotypes to social work as a whole, there are some who believe that the silence of social work on immigration issues reflects its reactionary and uncritical view of immigration policy (Humphries 2004). The increased awareness of prejudice towards immigrants may be one of the first steps toward making this issue more visible in social work.

One aim of this work is to suggest the inclusion of language in the study of anti-immigrant prejudice. In today's context, words matter more than ever. By means of inexpensive Internet, any social media user could spread anti-immigrant remarks at almost no cost, and these messages can reach to millions of users in a short period of time. This reality presents great challenges for social work to intervene. This emerging area is suitable for the interdisciplinary nature of social work research and may create an opportunity for a new research frontier. Social work may function as an interdisciplinary hub in which social work researchers can tap the resources of other disciplines to develop effective interventions that would increase individual empathy and sympathy in physical and virtual world. Social work researchers can work collaboratively with psychologists and cognitive scientists to design, implement, and evaluate these effectiveness and cultural competency of these interventions. Meanwhile, it is important to collaborate with researchers in data science who have the expertise in analyzing big data and provides data visualization tools for identifying target groups for intervention efforts. It would be also important for social work researchers to collaborate with scholars from law, political science, and international public policy in that immigration, by nature, is a political issue that requires changes in laws and policies.

Social workers should also aim to conduct qualitative research to further understand the lived experiences of immigrants and the role that anti-immigrant language has on their lives. Qualitative methods are best utilized to understand a phenomenon that is not yet fully known and where seeking the meaning of one's experience is central to the research (Denzin and Lincoln 2011). This is particularly relevant for understanding the experiences of immigrants, as the topic is under researched as a whole and that the understandings of their experiences is imperative towards developing quality and effective interventions to reduce anti-immigrant prejudice. One such proposal would be to interview individuals of various immigrant groups and ask about the effect that anti-immigrant language has on their identity, self-esteem and feelings of safety. In addition, such research should also seek to ask immigrants what terms they prefer to be used and are respectful of their culture, race, ethnicity and religion. As social workers, we must seek to empower others and allow them agency over their lives. This would provide an excellent opportunity for immigrants themselves to educate others on how they self-identify and on how best to reduce prejudice against them. This research would allow for in-depth conversations with immigrants to better understand their experiences as well as to begin to gather data on the ways in which would best reduce anti-immigrant prejudice and stigma from those most affected. Such research would allow us to best develop interventions that are effective and culturally competent.

\subsection{Implications for Social Work Practice}

School social workers can utilize existing prejudice-reduction interventions and implement them in educational settings, such as enrichment after school programs or multicultural programs (Perkins and Mebert 2005). Prejudice towards ethnic minorities was found to begin among children of three to six years old (Raabe and Beelmann 2011). In this case, early childhood interventions will help 
prevent children from developing negative attitudes towards out-group members. To develop positive attitudes and increase mutual respect and understanding, social workers may present materials without ethnic and racial bias (Bigler and Liben 2007), utilize role-playing, or provide moral explanations about not using prejudicial language (Aboud and Miller 2007). Such programs that conduct and assist with anti-bias training programs in the United States are the Anti-Defamation League, National Association for the Advancement of Colored People, UnidosUS, and Muslim Advocates, which are possible organizations for social workers to collaborate with to educate about diversity and to combat anti-immigrant prejudice. Social workers can actively work to implement aspects of teaching about diversity, racism, anti-bias and the history of immigrants into their classrooms at their respective universities, for bachelor, master and doctoral students of social work. Such initiatives are consistent with learning how the stigmatization of immigrants can often be a result of racism, socio-political historical factors and society's understanding of different groups at specific times in history, consistent with Howarth (2006), Crocker et al. (1998) and Link and Phelan (2001). School social workers can also implement such lessons into their curriculum with students in grades K-12. Furthermore, social workers in administrative positions at universities can advocate and implement for diversity trainings and mandatory curriculum development to address issues of race, culture, and religion into the campus environment.

Social workers in higher education are not solely limited to education in their classrooms. Social workers may also work to advocate for improving the campus environment to be more inclusive to immigrants both in the formation of student lead groups and the need for offices to address the needs of international students at their university. For example, students may work to ensure that immigrant students have resources available to them at the university and advocate for student led groups that work to address immigrant rights and provide a safe space towards students. Social workers may also collaborate with student unions, who are working to advocate for immigrants in the local community. In addition, social workers can work both on the campus level and the community level to declare their university and/or city a sanctuary university or city for immigrants. Each of these initiatives allows for a safer and more respectful environment for immigrants on their campus. This will allow for the rights of immigrants to be addressed on a macro-level.

While the empowerment of immigrants is still crucial at the individual level, how to covey macro-level efforts to immigrants may be one of the priorities in reducing structural barriers. Immigrants who are not aware of their legal rights in the United States are less likely to report being subjected to discrimination, harassment or hate crimes, including physical attacks. To empower immigrants, social work practitioners can help advise them of their legal rights, encourage them to report hate crimes, and organize immigrant residents to question anti-immigrant legislations (Shively et al. 2014). One of the recent efforts at federal level is the passage of Matthew Shepard and James Byrd Jr. Hate Crimes Prevention Act of 2009, which provides funding and assistance to state and local jurisdictions to investigate hate crimes (United States Congress 2010). It is important for social workers to be aware of this law as well as other laws that provide protection for immigrants and to inform them about their legal rights.

Promoting language changes in immigration policies and media may be comprised of important macro-level social work practices. In immigration policies, the word alien is used frequently. When immigrants become permanent residents, they will receive a green card, which has a neutral connotation on its own. However, the green card is also called the United States Alien Registration Receipt Card, and a green card holder is also called resident alien. The word alien is often accompanied with negative terms such as abduction, and this, in turn, may lead people to automatically and unintentionally associate immigrants with extraterrestrial others and extraterrestrial abduction (Nunez 2013). The other identified derogatory word is illegal, a word criminalizing immigrant groups (Furman et al. 2012). Social workers can promote the change of words with negative connotations to alternatives with neutral or benign words in policies and in mass media. This change is possible because many linguists, Latino/a/ $x$ and immigration activists, and students from Dartmouth College 
are actively promoting the change of derogatory words (Padilla and Rivera 2016). One of the most recent promising outcomes was the response from the Library of Congress (2016), who has agreed that the term illegal aliens is an offensive term and announced it would no longer use it as a bibliographical term. While there are many challenges in research, there is an even larger amount of opportunities for social workers to promote equality and acceptance of immigrants.

In conclusion, historical and contemporary events reveal the important role of language in the creation, transmission, and perpetuation of anti-immigrant prejudice. As a review of the historical literature has shown, the status of being an immigrant is a stigma, regardless of the specific immigrant group. Building upon prior theoretical conceptualizations of stigma, we define being an immigrant as a stigma, which allows us to tailor interventions and research in order to reduce the anti-immigrant prejudice. The investigation of language in the study of prejudice would be one of the first steps towards understanding stigmatization of immigrants and addressing structural barriers to equality. Promoting changes in the language used in immigration policies and in media discussion of immigration issues may constitute an important area of social work practice. The need to advocate for immigrants in policy, research and education is urgent in order to best enhance the well-being of all immigrants in the United States.

Author Contributions: Conceptualization, K.W. and S.W.; literature, K.W. and D.L.; writing—original draft preparation, K.W.; writing-review and editing, D.L. and S.W.; supervision, S.W.

Funding: This research received no external funding.

Conflicts of Interest: The authors declare no conflict of interest.

\section{References}

Aboud, Frances, and Lior Miller. 2007. Promoting peer intervention in name-calling. South African Journal of Psychology 37: 803-19. [CrossRef]

Addams, Jane. 1990. Twenty Years at Hull-House with Autobiographical Notes. Champaign: University of Illinois Press.

Albrecht, Gary L., Vivian G. Walker, and Judith A. Levy. 1982. Social distance from the stigmatized: A test of two theories. Social Science \& Medicine: 16: 1319-27.

Ali, Yaser. 2012. Shariah and citizenship-How islamophobia is creating a second-class citizenry in America. California Law Review 100: 1027.

Allport, Gordon W. 1954. The Nature of Prejudice. Boston: Addison-wesley.

Allport, Gordon Willard, Kenneth Clark, and Thomas Pettigrew. 1954. The Nature of Prejudice. Boston: Addison-Wesley.

Alsultany, Evelyn. 2012. Arabs and Muslims in the Media: Race and Representation after 9/11. New York: NYU Press.

Alsultany, Evelyn. 2013. Arabs and Muslims in the media after 9/11: Representational strategies for a "postrace" era. American Quarterly 65: 161-69. [CrossRef]

Arnold, Kathleen R. 2011. Anti-Immigration in the United States: A Historical Encyclopedia. Santa Barbara: ABC-CLIO, vol. 2.

Awan, Imran, and Irene Zempi. 2015. 'I will Blow your face off' - Virtual and Physical World Anti-Muslim Hate Crime. British Journal of Criminology 57: 362-80. [CrossRef]

Bakshy, Eytan, Solomon Messing, and Lada A. Adamic. 2015. Exposure to ideologically diverse news and opinion on Facebook. Science 348: 1130-32. [CrossRef] [PubMed]

Barrett, James R. 1992. Americanization from the bottom up: Immigration and the remaking of the working class in the United States, 1880-1930. The Journal of American History 79: 996-1020. [CrossRef]

Barth, Gunther Paul. 1964. Bitter Strength: A History of the Chinese in the United States, 1850-1870. Cambridge: Harvard University Press.

Berger, Max. 1946. The Irish Emigrant and American Nativism as Seen by British Visitors, 1836-1860. The Pennsylvania Magazine of History and Biography 70: 146-60.

Bigler, Rebecca S., and Lynn S. Liben. 2007. Developmental intergroup theory explaining and reducing children's social stereotyping and prejudice. Current Directions in Psychological Science 16: 162-66. [CrossRef] 
Calavita, Kitty. 1984. U.S. Immigration Law and the Control of Labor, 1820-1924. Cambridge: Academic Press.

Carnaghi, Andrea, and Anne Maass. 2007. In-Group and Out-Group Perspectives in the Use of Derogatory Group Labels Gay Versus Fag. Journal of Language and Social Psychology 26: 142-56. [CrossRef]

Carrigan, William D., and Clive Webb. 2003. The lynching of persons of Mexican origin or descent in the United States, 1848 to 1928. Journal of Social History 37: 411-38. [CrossRef]

Casey, Marion, and J. Lee. 2007. Making the Irish American: History and Heritage of the Irish in the United States. New York: NYU Press.

Cervantes, Richard C., Amado M. Padilla, Lucy E. Napper, and Jeremy T. Goldbach. 2013. Acculturation-related stress and mental health outcomes among three generations of Hispanic adolescents. Hispanic Journal of Behavioral Sciences 35: 451-68. [CrossRef]

Chavez, Leo. 2013. The Latino Threat: Constructing Immigrants, Citizens, and the Nation. Palo Alto: Stanford University Press.

Cole, David. 2009. Out of the shadows: Preventive detention, suspected terrorists, and war. California Law Review 97: 693-750.

Collins, Katherine A., and Richard Clément. 2012. Language and prejudice: Direct and moderated effects. Journal of Language and Social Psychology 31: 376-96. [CrossRef]

Crenson, M. A. 1998. Building the Invisible Orphanage: A Prehistory of the American Welfare System. Cambridge: Harvard University Press.

Crocker, Jennifer, Brenda Major, Claude Steele, Susan T. Fiske, and Gardner Lindzey. 1998. Social stigma. In Handbook of Social Psychology, 4th ed. Edited by Susan T. Fiske, Daniel T. Gilbert and Gardner Lindzey. New York: Academic Press.

Denzin, Norman K., and Yvonna S. Lincoln, eds. 2011. The Sage Handbook of Qualitative Research. Thousands Oaks: Sage.

Derose, Kathryn Pitkin, José J. Escarce, and Nicole Lurie. 2007. Immigrants and health care: Sources of vulnerability. Health Affairs 26: 1258-68. [CrossRef] [PubMed]

Dorland, Chester P. 1894. Chinese Massacre at Los Angeles in 1871. Woodbridge: Twayne Publishers.

Dred Scott v. Sandford. 1857, 60 U.S. 393 C.F.R.

Elliott, Gregory C., Herbert L. Ziegler, Barbara M. Altman, and Deborah R. Scott. 1982. Understanding stigma: Dimensions of deviance and coping. Deviant Behavior 3: 275-300. [CrossRef]

FBI. 2001. Uniform Crime Reports. Available online: https://ucr.fbi.gov/crime-in-the-u.s/2001 (accessed on 7 March 2019).

Feldberg, Michael. 1975. The Philadelphia Riots of 1844: A Study of Ethnic Conflict. Westport: Greenwood Press.

Fiedler, Klaus. 2011. Social Communication. New York: Psychology Press.

Fujioka, Yuki. 2011. Perceived threats and Latino immigrant attitudes: How White and African American college students respond to news coverage of Latino immigrants. The Howard Journal of Communications 22: 43-63. [CrossRef]

Furman, Rich, Alissa R. Ackerman, Melody Loya, Susanna Jones, and Nalinin Egi. 2012. The Criminalization of Immigration: Value Conflicts for the Social Work Profession. Journal of Sociology and Social Welfare 39: 169. [PubMed]

Gambino, Richard. 1977. Vendetta: A True Story of the Worst Lynching in America, the Mass Murder of Italian-Americans in New Orleans in 1891, the Vicious Motivations Behind It, and the Tragic Repercussions that Linger to This Day. New York: Doubleday Books.

Goffman, Erving. 1963. Stigma: Notes on the Management of Spoiled Identity. New York: Simon \& Schuster Inc.

Goloboy, Jennifer L. 2009. Industrial Revolution; People and Perspectives. Santa Barbara: ABC-CLIO.

Gonzalez-Barrera, Ana, and Jens Krogstad. 2015. What We Know about Illegal Immigration from Mexico. Available online: http:/ / www.pewresearch.org/fact-tank/2015/11/20/what-we-know-about-illegal-immigrationfrom-mexico/ (accessed on 7 March 2019).

Gordon, Milton M. 1964. Assimilation in American Life: The Role of Race, Religion, and National Origins. New York: Oxford University Press on Demand.

Gyory, Andrew. 1998. Closing the Gate: Race, Politics, and the Chinese Exclusion Act. Chapel Hill: University of North Carolina Press.

Hall, Stuart. 1980. Encoding/decoding. In Centre for Contemporary Cultural Studies: Culture, Media, Language. Working Papers in Cultural Studies, 1972-1979. London: Hutchinson, pp. 128-38. 
Handlin, Oscar. 1941. Boston's Immigrants, 1790-1865: A Study in Acculturation. Cambridge: Harvard University Press.

Higham, John. 2002. Strangers in the Land: Patterns of American Nativism, 1860-1925. New Brunswick: Rutgers University Press.

Houstoun, Mrs. 1850. Hesperos: Or, Travels in the West. London: J.W. Parker.

Howarth, Caroline. 2006. Race as stigma: Positioning the stigmatized as agents, not objects. Journal of Community $\mathcal{E}$ Applied Social Psychology 16: 442-51.

Humphries, Beth. 2004. An unacceptable role for social work: Implementing immigration policy. British Journal of Social Work 34: 93-107. [CrossRef]

Huntington, Samuel P. 2004. Who Are We?: The Challenges to America's National Identity. New York: Simon and Schuster.

Igartua, Juan-José, Félix Moral-Toranzo, and Itziar Fernández. 2012. Cognitive, attitudinal, and emotional effects of news frame and group cues, on processing news about immigration. Journal of Media Psychology 23: 174-85. [CrossRef]

Jost, John T., and Aaron C. Kay. 2010. Social justice: History, theory, and research. In Handbook of Social Psychology. Edited by Susan T. Fiske, Daniel T. Gilbert and Gardner Lindzey. Hoboken: John Wiley, vol. 2, pp. 1122-65.

Kennedy, David M. 2004. Over Here: The First World War and American Society. New York: Oxford University Press.

Kennedy, John Fitzgerald, and Robert Francis Kennedy. 1964. A Nation of Immigrants. New York: Harper \& Row.

Kohn, Sally. 2015. Trump's Outrageous Mexico Remarks. Available online: http:/ /www.cnn.com/2015/06/17/ opinions / kohn-donald-trump-announcement/ (accessed on 7 March 2019).

Kundnani, Arun. 2014. The Muslims Are Coming!: Islamophobia, Extremism, and the Domestic War on Terror. New York: Verso Books.

Kurzban, Robert, and Mark R. Leary. 2001. Evolutionary origins of stigmatization: The functions of social exclusion. Psychological Bulletin 127: 187. [CrossRef] [PubMed]

Kusow, Abdi M. 2004. Contesting stigma: On Goffman's assumptions of normative order. Symbolic Interaction 27: 179-97. [CrossRef]

LaGumina, Salvatore J. 1999. Wop!: A Documentary History of Anti-Italian Discrimination in the United States. Toronto: Guernica Editions.

Lakoff, George, and Mark Johnson. 2008. Metaphors We Live By. Chicago: University of Chicago Press.

Lara, Marielena, Cristina Gamboa, M. Iya Kahramanian, Leo S. Morales, and David E. Hayes Bautista. 2005. Acculturation and Latino health in the United States: A review of the literature and its sociopolitical context. Annual Review of Public Health 26: 367-97. [CrossRef] [PubMed]

Library of Congress. 2016. Library of Congress to Cancel the Subject Heading "Illegal Aliens". Available online: https: / / www.loc.gov/catdir/cpso/illegal-aliens-decision.pdf (accessed on 7 March 2019).

Lichtablau, Eric. 2015. Crimes against Muslim Americans and Mosques Rise Sharply. The New York Times. Available online: http: / www.nytimes.com/2015/12/18/us / politics / crimes-against-muslim-americansand-mosques-rise-sharply.html?smid=tw-nytimes\&smtyp=cur\&_r=0 (accessed on 7 March 2019).

Link, Bruce G., and Jo C. Phelan. 2001. Conceptualizing stigma. Annual Review of Sociology 27: 363-85. [CrossRef]

López, María Pabón. 2012. Essay Examining the Murder of Luis Ramirez and the Emergence of Hate Crimes against Latino Immigrants in the United States. Arizona State Law Journal 44: 155.

Lopez-Class, Maria, Felipe González Castro, and Amelie G. Ramirez. 2011. Conceptions of acculturation: A review and statement of critical issues. Social Science \& Medicine 72: 1555-62.

Maass, Anne. 1999. Linguistic intergroup bias: Stereotype perpetuation through language. Advances in Experimental Social Psychology 31: 79-121.

MacDougall, Robert. 1999. Red, brown and yellow perils: Images of the American enemy in the 1940s and 1950s. The Journal of Popular Culture 32: 59-75. [CrossRef]

Major, Brenda, and Laurie T. O’Brien. 2005. The social psychology of stigma. Annual Review of Psychology 56: 393-421. [CrossRef] [PubMed]

Martineau, Harriet. 1837. Society in America. New York: Saunders and Otley.

Massey, Douglas S., and Karen A. Pren. 2012. Unintended consequences of US immigration policy: Explaining the post-1965 surge from Latin America. Population and Development Review 38: 1-29. [CrossRef] [PubMed]

Matthews, Lear. 2003. Coping in the aftermath of the World Trade Center tragedy: An immigrant perspective. Journal of Immigrant $\mathcal{E}$ Refugee Services 1: 101-8. 
Minoff, Elisa. 2018. Instutional racism and the urgent need to transform public systems that separate families. Center for the Study of Social Policy. Available online: https:/ / cssp.org/2018/11/institutional-racism-andthe-urgent-need-to-transform-public-systems-that-separate-families/ (accessed on 7 March 2019).

Mitchell, David W. 1862. Ten Years in the United States: Being an Englishman's View of Men and Things in the North and South. London: Smith, Elder \& Co.

Miyao, Daisuke. 2007. Sessue Hayakawa: Silent Cinema and Transnational Stardom. Durham: Duke University Press.

Monotgomery, J. 2013. Ray Suarez on “Latino Americans”. Available online: http://kuow.org/post/ray-suarezlatino-americans (accessed on 7 March 2019).

Mormino, Gary R. 2002. Immigrants on the Hill: Italian-Americans in St. Louis, 1882-1982. Columbia: University of Missouri Press.

NASW (National Association of Social Workers). 2008. Code of Ethics of the National Association of Social Workers. Available online: https:/ / www.socialworkers.org/LinkClick.aspx?fileticket=KZmmbz15evc\%3D\& portalid=0 (accessed on 2 February 2019).

Nunez, D. 2013. War of the words: Aliens, immigrants, citizens, and the language of exclusion. BYU Law Review 6, 1517-61.

Padilla, S., and S. Rivera. 2016. Library of Congress to Stop Using Term 'Illegal Alien'. Available online: http:/ / www.latimes.com/nation/la-na-library-congress-alien-20160403-story.html (accessed on 7 March 2019).

Padilla, Yolanda C., Ester R. Shapiro, Mónica D. Fernández-Castro, and Monica Faulkner. 2008. Our nation's immigrants in peril: An urgent call to social workers. Social Work 53: 5. [CrossRef] [PubMed]

Park, Robert E. 1914. Racial assimilation in secondary groups with particular reference to the Negro. The American Journal of Sociology 19: 606-23. [CrossRef]

Passel, Jeffrey, and DVera Cohn. 2014. Chapter 2: Birthplaces of U.S. Unauthorized Immigrants. Pew Research Center, Washington. Available online: http:/ / www.pewhispanic.org/2014/11/18/chapter-2-birthplaces-ofu-s-unauthorized-immigrants / (accessed on 7 March 2019).

Pearson, Matthew R. 2010. How "undocumented workers" and "illegal aliens" affect prejudice toward Mexican immigrants. Social Infulence 5: 118-32. [CrossRef]

People v. Hall. 1854, Cal. 399 C.F.R.

Pérez, Efrén O. 2010. Explicit evidence on the import of implicit attitudes: The IAT and immigration policy judgments. Political Behavior 32: 517-45. [CrossRef]

Perkins, Donna M., and Carolyn J. Mebert. 2005. Efficacy of Multicultural Education for Preschool Children A Domain-Specific Approach. Journal of Cross-Cultural Psychology 36: 497-512. [CrossRef]

Peterson, Horace Cornelius, and Gilbert Courtland Fite. 1986. Opponents of War, 1917-1918. Santa Barbara: Greenwood Publishing Group.

Pew Research Center. 2017. Key Findings about U.S. Immigrants. Available online: http:/ /www.pewresearch. org/fact-tank/2017/05/03/key-findings-about-u-s-immigrants / (accessed on 7 March 2019).

Porter, Shanette C., Michelle Rheinschmidt-Same, and Jennifer A. Richeson. 2015. Inferring Identity from Language Linguistic Intergroup Bias Informs Social Categorization. Psychological Science 27: 94-102. [CrossRef] [PubMed]

Provine, Doris Marie. 2007. Unequal Under Law: Race in the War on Drugs. Chicago: University of Chicago Press.

Raabe, Tobias, and Andreas Beelmann. 2011. Development of ethnic, racial, and national prejudice in childhood and adolescence: A multinational meta-analysis of age differences. Child Development 82: 1715-37. [CrossRef] [PubMed]

Richardson, James Daniel. 1908. A Compilation of the Messages and Papers of the Presidents, 1789-1908. Charleston: ReInk Books.

Robinson, Greg. 2009. A Tragedy of Democracy: Japanese Confinement in North America. New York: Columbia University Press.

Sabo, Samantha, Susan Shaw, Maia Ingram, Nicolette Teufel-Shone, Scott Carvajal, Jill Guernsey de Zapien, Cecilia Rosales, Flor Redondo, Gina Garcia, and Raquel Rubio-Goldsmith. 2014. Everyday violence, structural racism and mistreatment at the US-Mexico border. Social Science E Medicine 109: 66-74.

Santa Ana, Otto. 2002. Brown Tide Rising: Metaphors of Latinos in Contemporary American Public Discourse. Austin: University of Texas Press. 
Scheufele, Dietram A., and David Tewksbury. 2007. Framing, agenda setting, and priming: The evolution of three media effects models. Journal of Communication 57: 9-20. [CrossRef]

Sheehi, Stephen. 2011. Islamophobia: The Ideological Campaign against Muslims. Atlanta: Clarity Press.

Sheridan, Lorraine P. 2006. Islamophobia pre- and post-September 11th, 2001. Journal of Interpersonal Violence 21: 317-36. [CrossRef] [PubMed]

Shively, Michael, Rajen Subramanian, Omri Drucker, Jared Edgerton, Jack McDevitt, Amy Farrell, and Janice Iwama. 2014. Understanding Trends in Hate Crimes Against Immigrants and Hispanic-Americans. Cambridge: Abt Associates.

Sidiqqui, Sabrina. 2018. Trump's Travel ban. What Does the Supreme Court Ruling Mean? Available online: https:/ / www.theguardian.com/us-news/2018/jun/26/trump-travel-ban-supreme-court-ruling-explained (accessed on 7 March 2019).

Stafford, Mark C., and Richard R. Scott. 1986. Stigma, deviance, and social control. In The Dilemma of Difference. Boston: Springer, pp. 77-91.

Stets, Jan E., and Peter J. Burke. 2000. Identity theory and social identity theory. Social Psychology Quarterly 63: 224-37. [CrossRef]

Streitmatter, Rodger. 1999. The nativist press: Demonizing the American immigrant. Journalism $\mathcal{E}$ Mass Communication Quarterly 76: 673-83.

Takaki, Ronald T. 1990. Iron Cages: Race and Culture in 19th-Century America. New York: Oxford University Press.

United States Congress. 2010. The Matthew Shepard Hate Crimes Prevention Act of 2009: Hearing before the Committee on the Judiciary, United States Senate, One Hundred Eleventh Congress, First Session, June 25, 2009. Washington, D.C.: U.S. Government Printing Office, June 25.

Webb, Stephen A. 2006. Social Work in a Risk Society: Social and Political Perspectives. Basingstoke: Palgrave Macmillan.

White, Campbell, Julie M. Duck, and Peter A. Newcombe. 2012. The impact of media reliance on the role of perceived threat in predicting tolerance of Muslim cultural practice. Journal of Applied Social Psychology 42: 3051-82. [CrossRef]

Yang, Lawrence Hsin, Arthur Kleinman, Bruce G. Link, Jo C. Phelan, Sing Lee, and Byron Good. 2007. Culture and stigma: adding moral experience to stigma theory. Social Science E Medicine 64: 1524-35.

Young, Elliott. 2014. Alien Nation: Chinese Migration in the Americas from the Coolie Era through World War II. Chapel Hill: UNC Press Books.

Young, Sean D., A. David Nussbaum, and Benoît Monin. 2007. Potential moral stigma and reactions to sexually transmitted diseases: Evidence for a disjunction fallacy. Personality and Social Psychology Bulletin 33: 789-99. [CrossRef] [PubMed]

(C) 2019 by the authors. Licensee MDPI, Basel, Switzerland. This article is an open access article distributed under the terms and conditions of the Creative Commons Attribution (CC BY) license (http://creativecommons.org/licenses/by/4.0/). 